RESEARCH ARTICLE

\title{
First-Year Student Transition at the University of the Free State during COVID-19: Challenges and Insights
}

\author{
Herkulaas M.v.E. Combrink ${ }^{\star} \&$ Lauren L. Oosthuizen ${ }^{\star \star}$
}

\begin{abstract}
First-year seminars and university induction programmes are embedded with academic and social skills required by students to transition into their first year of study. The first-year seminar at the University of the Free State is a credit-bearing module called UFS101, and is a prerequisite for degree completion. Students are assessed through summative assessment opportunities throughout the year. In 2020, the UFS101 module embarked on new territory by condensing the contact time for the first semester into a week-long summer school. Furthermore, the summer school was presented a week prior to the start of university, with repeat sessions during the first week of class, and during the March holiday. However, due to national lockdown regulations as a result of COVID-19, a part of the cohort had to self-study the content via an interactive online study guide. This created four distinct groups of students: those who attended face-to-face classes, some face-to-face classes and some self-study, self-study only, and students who could not access the content. In order to measure their transition into university, a questionnaire was distributed to the students, and the results were stratified according to one of the aforementioned categories. Unique similarities and differences were observed in the findings. The results depict that effective content design is at the heartbeat of student transition, but that other factors such as face-to-face interaction with students, and access to resources assist with the transition into university. This study highlighted the need to explore the challenges students experience within their first six months at university, and substantiates that this type of exploration should be routinely conducted to assist with the understanding and implementation of first-year student support.
\end{abstract}

\section{Keywords}

COVID-19; first-year seminar; summer school; student transition; UFS101

\section{The First-Year Experience and First-Year Seminars}

The first-year experience (FYE) is a concept broadly used to describe different academic and non-academic interventions that form part of the first year of study within higher education (Tinto \& Goodshell, 1994). The purpose of a FYE is to assist first-year students' academic and social integration into higher education institutions (Evans \& Morrison, 2011).

* Mr Herkulaas M.v.E. Combrink is a Research Coordinator at the Centre for Teaching and Learning at the University of the Free State, South Africa. Email: combrinkhm@ufs.ac.za

** Mrs Lauren L. Oosthuizen is an Assistant Director for First Year Transition and Graduate Attributes at the Centre for Teaching and Learning, University of the Free State, South Africa. Email: hingll@ufs.ac.za 
The FYE includes induction programmes such as orientation, and co-curricular interventions such as mentoring, student societies, and first-year seminars (FYS) (Crissman, 2001).

A FYS, also typically referred to as a University 101 programme, was first introduced to students at the University of South Carolina (USC) in 1964 (Townsend, 1994). The purpose of an FYS is to act as a vehicle to successfully integrate students into the university environment, as well as embed academic and social skills to be successful within university (Fallows \& Steven, 2000). The reason for having both the social and academic integration strategies within a FYE and FYS relates to the high drop-out rates associated with students feeling disconnected and overwhelmed in the university space (Yan \& Sendall, 2016). This statement explicitly encompasses differences encountered in the preparedness of different groups of students on the premise of their context which includes their background, high school education and socio-economic status, and is supported by different studies (Thomsen, 2012; Ulriksen et al., 2017).

According to Ulriksen et al. (2017), in order to understand student drop out and the strategies that universities can implement, an explicit effort has to be made by each institution to identify this gap, and apply it within the university's FYS space to address the needs students experience that complicate student transition. This means that a FYS will differ between institutions and that they will include teaching a variety of skills related to academic requirements for a specific institution as well as basic social skills (Gellin, 2003). Gellin (2003) further argued that although these skills are vital for university success and employment, the body of knowledge is limited regarding the impact of different institutional initiatives related to student transition.

Several studies assessed the value of a FYS, and whether or not a FYS assists a student to transition into the university environment and found that the value of an FYS is to foster a sense of belonging and map the academic expectations for a first-year university student (Starke et al., 2001; Porter \& Swing, 2006; Buyarski \& Landis, 2014). Tinto (1987) argued that students with a lower rate of academic success or institutional engagement are more likely to drop out of university. The argument was supported by six potential causes of student departure out of universities namely: adjustment, goals, commitments, uncertainty, congruence, and isolation - all of which are related to either social or academic adjustment, or a combination of both. Upcraft et al., (2005) added to Tinto's (1987) argument by providing tangible evidence suggesting that student transition is much more than the skills taught, and that the value of a FYS lies in the improvement of persistence through the combination of both social and academic skills, and not just the academic skills alone (Upcraft \& Gardner, 1989; Upcraft et al., 2005). This means that FYS programmes have a clear focus on student transition from a social and academic perspective, unique to each institution. Kuh (2008) positioned FYS programmes as High Impact Practices (HIPs).

Kuh (2008) further proved that FYS programmes form part of a vast school of thought about theoretical and practical interventions that promote student success. This school of thought is geared towards student success by enabling deeper learning, a concept known as "student engagement" (Kuh, 2008). HIPs are academic activities that have shown to 
improve student engagement, retention and graduation rates when students participate in them. According to Myers et al. (2019), the larger goal of HIPs relates to better university outcomes and includes a knowledge of cultures, strong intellectual and practical skills, and a sense of civic responsibility and community engagement, amongst others.

\section{UFS101 as the FYS at the University of the Free State}

To date, the concept of a FYS has expanded globally and is presented in a variety of higher education landscapes outside the United States, including universities and colleges in Germany, Austria, France, Korea, Great Britain, Australia and South Africa (Barefoot, 2004). Within the context of South Africa, the aim of a FYS is to foster a sense of belonging or institutional connectedness, introduce campus services and teach the academic skills required to be successful at university (Young, 2016). Furthermore, the theoretical underpinnings of a FYS for student transition within the context of South Africa have been investigated, emphasising a dimension related to student agency and personal responsibility as part of the transition process (Stoller, 2019).

The mode of delivery is different between the varieties of FYS programmes within institutions of higher learning across the world. Some are positioned as workshops in the co-curricular space, while others formally form part of the curriculum as credit-bearing modules with specific passing criteria (Culver \& Bowman, 2019). Although the concept of a FYS has only been in implementation for less than a decade in the context of South African higher education, the FYS at the University of the Free State (UFS) has been in full roll-out since 2012. The FYS at the UFS (UFS101) is a credit-bearing, year-long module. This module is required for degree completion by all students, across all disciplines, in their first academic year of study. It is implemented across two UFS campuses, namely the Bloemfontein (BFN) and QwaQwa (QQ) campuses. The number of students registered for this module has increased from 2000 students in 2012 to more than 8000 students in 2019 .

One of the primary goals of this module is to equip students with the skills they require in order to successfully integrate socially and academically into the UFS environment. The basis of the pedagogical model used is rooted in student engagement, the needs of the UFS, and the strategic vision from the Department of Higher Education and Training (DHET) in South Africa (Kuh, 2008, DHET, 2017). Since 2015, there have been two distinct focuses in UFS101 each year. The content presented in the first semester is exclusively positioned as a FYS, with the focus on transitioning students into university by teaching the academic skills vital for university success. The second semester, although still within the space of a FYS, is positioned around common intellectual experiences to prepare students for the workforce by introducing them to strategies for lifelong success, and graduate attributes such as an entrepreneurial mindset, and leadership skills. Challenges have been noted within the context of South African universities that extend beyond what a University 101 programme can teach, but by embedding student engagement strategies within the FYS, the institutional transition for the South African context is strengthened from an evidencebased perspective (Strydom et al., 2017). 


\section{Positioning the First Semester of UFS101 as a Summer School}

In 2020, there was a strategic shift to position the first semester of UFS101 as a summer school within the UFS context. The rationale for this change was motivated by institutional evidence, illustrating that fast tracking the skills students require at university assists with their transition to university. Summer schools are common practices across the world (Achille et al., 2018; Vinas-Forcade et al., 2019). Summer schools typically fall into three categories, namely (a) summer exchange programme; (b) a module presented in a condensed version in order to repeat or lighten credit load during the semester; and (c) summer bridge course (Colombo \& Falcone, 2016; Chastonay \& Mpinga, 2018; EblenZayas \& Russell, 2019). The impact of summer school programmes in this context have been studied across various disciplines (Tomasko et al., 2016; Cooper et al., 2017).

Some of the more pronounced benefits of summer school programmes are preparation for university, as well as the skills needed to function in the world of work, and the introduction of non-technical skills pivotal to student success (Bir \& Myrick, 2015). Another benefit of a summer school programme is the enabling of equitable education for students from diverse secondary schooling backgrounds through the teaching of academic skills required to be successful at university (Kretovics et al., 2005; Larsen et al., 2017). These benefits of a summer school align with the objectives of a FYS, and the relationship between these programmes has been studied extensively (Chism, 2008; Strayhorn, 2009; Hansen \& Schmidt, 2017; Velazquez-Torres, 2018).

The change in UFS101 would fall into the category of a summer bridge course, but will be referred to as a summer school within the context of this study. This is because not all students would be taught the skills they need to be successful at university before they start with their academic course work - the reasoning is detailed in the paragraph below.

Due to the administrative load and logistics required to navigate the large cohort of UFS101 the attendees of the summer school were split into three groups, to respond to the observed registration patterns of first-year students. The students in group one were directed to attend both UFS101 and Orientation as both programmes were presented in the same week, before the start of the semester. Orientation in this instance refers to the institutional first-year orientation programme, intended to help students navigate university systems, introduce students to university life and promote resources students can engage with to assist their journey - such as library information sessions, art and cultural activities and student support structures. In group two, the faculties agreed to allot 10 hours in the timetable to UFS101, in the first week of the semester. Group three was scheduled to attend the summer school during the March break.

Table 1 is an overview and account for the three groups of the summer school that took place in 2020 . 
Table 1: Group allocation for the UFS101 2020 summer school

\begin{tabular}{|l|l|l|}
\hline Group & Date & Student register by \\
\hline Group 1 & 27-31 January 2020 & 23 January 2020 \\
\hline Group 2 & 3-8 February 2020 & 31 January 2020 \\
\hline Group 3 & March break & Late registers \\
\hline
\end{tabular}

\section{0 and COVID-19}

The disease COVID-19, was reported in sub-Saharan Africa on 29 January 2020, and the first reported case appeared in South Africa on 5 March 2020 (Osseni, 2020). Innovative solutions were created to share information with the South African public about the disease in the initial stages of the pandemic, but there remained a high degree of uncertainty of what the pandemic would mean for all sectors of the economy (Marivate \& Combrink, 2020). To avoid a national disaster in the context of a highly infectious and poorly understood disease, the South African government initiated a state of disaster and a national lockdown that suspended all but the most critical economic functions (Amir Singh, 2020). This lockdown was introduced as a five-level strategy, each having an impact on certain sectors of the South African economy (Hatefi et al., 2020). As a result, institutions of higher learning shut down, and academic activities had to rapidly move online.

This shift had significant implications for the UFS101 module as the third group, which comprised a combination of students who registered late, and students who missed a few sessions in either group one or two, were supposed to attend the summer school during the March break and could not do so as a result of the national lockdown. The academic skills were presented in a workshop-like setting to groups one and two, and made available to students on Blackboard, the university's Learning Management System. For group three, the content had to quickly be converted to a low-tech self-study guide that students could download from Blackboard and work through offline. The UFS101 outcomes and assessments remained the same, but the teaching activities, mode of delivery and timelines had to be adapted for emergency remote teaching and learning. The move to emergency remote teaching and learning resulted in the decision to convert the content to a low-tech self-study guide, while the institution (and country) was working on ways to support students to participate in online learning.

The national lockdown's effect on the mode of delivery meant that there were now new groupings of students - students who had attended the summer school face-to-face, students who had attended some of the classes face-to-face and some self-study, students who engaged only with the self-study content, and students who did not attend face-toface classes and could not access the self-study guide. Therefore, the aim of this study was to apply a qualitative inquiry on the UFS101 student population for 2020, related to their transition into university. 


\section{Methodology}

An online questionnaire was administered from the 7 July 2020 to 7 August 2020 to students registered for UFS101. These quantitative questions were adapted from Morse (2010), and focused on student transition. The online questionnaire was low-tech (less than $1 \mathrm{MB}$ ) and mobile friendly, however sampling error could have been caused through the exclusion of students who did not have access to a device, data or internet connectivity (Morse, 2010). All the quantitative questions were illustrated, tabulated and analysed using Python version 3.7. ${ }^{1}$

In the analysis, a descriptive examination was performed on the categorical variables to gain contextual perspectives between the different stratified groups. This approach is supported by the research of Boeije (2013), where it is noted that this type of research design contributes towards new knowledge of the investigation by laying a foundation for future research, while focusing on the fundamental description required in order to gain a generalised understanding of the study population (Boeije et al., 2013). The analysis of quantitative information assists with the identification of trends and defines different areas that require improvement, as illustrated in the recommendations of this study. The interpretive framework created by the paradigm draws from interpretivism (Henderson, 2011; Ricciardi, 2009). This methodology is desirable for addressing the proposed research questions in the context of large cohorts (Morse, 2010; Sreejesh \& Mohapatra, 2014). Additionally, none of the findings of this study contain any identifiable characteristics or data linking the evidence to a specific student. Ethical clearance was granted under the scope of UFS-HSD2017/0206 in 2017 and remains active until September 2021, with the required amendments made to the protocol in order to conduct this research.

\section{Results and Discussion}

\section{Participants}

In Table 2, the distribution across faculty and campus of the 1933 participants is illustrated. There are seven faculties on the BFN campus and four faculties on the QQ campus. In total, $38.6 \%$ of students on the BFN campus and $37.5 \%$ of students on the QQ campus completed the questionnaire.

1 Python Packages: Pandas and Numpy 
Table 2: Demographic distribution of the study population

\begin{tabular}{|l|c|c|}
\hline Faculty & BFN (n=1587) & QQ (n=346) \\
\hline Faculty Economic \& Mgnt Sciences & $18.6 \%$ & $11.3 \%$ \\
\hline Faculty of Natural \& Agri Sciences & $19.3 \%$ & $3.8 \%$ \\
\hline Faculty of Theology & $0.3 \%$ & $0.0 \%$ \\
\hline Faculty of Education & $24.4 \%$ & $61.6 \%$ \\
\hline Faculty of Health Sciences & $10.0 \%$ & $0.0 \%$ \\
\hline Faculty of Law & $5.9 \%$ & $0.0 \%$ \\
\hline Faculty of the Humanities & $21.4 \%$ & $23.4 \%$ \\
\hline
\end{tabular}

In order to understand which mode of delivery the students belonged to, the information was stratified in four categories: face-to-face classes at the start of the year; some face-toface classes and some self-study; no face-to-face classes and complete self-study, and could not access the UFSS101 content (Table 3).

Table 3: Different modes of delivery were experienced by students on the premise of the lockdown

\begin{tabular}{|l|c|c|}
\hline Category & BFN (n=1587) & QQ (n=346) \\
\hline Face-to-face & $60.6 \%$ & $49.7 \%$ \\
\hline Some face-to-face, some self-study & $16.0 \%$ & $26.9 \%$ \\
\hline Self-study only & $21.9 \%$ & $19.9 \%$ \\
\hline Could not access content & $1.5 \%$ & $3.5 \%$ \\
\hline
\end{tabular}

\section{Measurement of challenges and transition}

Students were asked what were the biggest challenges experienced within the first six months at university (Table 4), whether or not UFS101 assisted their transition (Table 5), how UFSS101 assisted their transition (Figure 1), and the positive vs negative experiences of UFS101 (Figure 2). Students who participated in the questionnaire were stratified amongst four groups, namely: face-to-face $(n=1133)$; some face-to-face and some selfstudy ( $n=347)$; self-study only $(n=417)$; and, could not access the content $(n=36)$.

As shown in Table 4, time management was the biggest challenge experienced by both face-to-face students (60\%) as well as self-study students (56\%). An interesting observation can be seen between the students who could not access the content and did not have access to the internet (64\%), and their concern with where to find academic support (44\%). Overall, the majority of the students reported time management, difficulty adjusting to the new environment, and how to effectively study as their biggest challenges. This coincides with findings from Mah \& Ifenthaler (2017), and Adams \& Blair (2019), measuring academic success and time management of first-year students, and the challenges associated 
with this. Although only a small percentage (3\% to $17 \%$ ) reported food security and accommodation as challenges, this highlights the complexity of challenges that university students face. These findings coincide with that of Van Breda (2017), who highlighted the levels of vulnerability students face that have an impact on their academic performance. In addition to this, Henn et al. (2017) reported that there are first-year students within the South African context who are faced with constant hunger and stress related to their finances, also seen as a challenge in Table 4. In addition to this, no electronic devices was a challenge observed by all groups.

Table 4: Challenges students experienced within their first six months

\begin{tabular}{|l|c|c|c|c|}
\hline Challenge & $\begin{array}{c}\text { Face- } \\
\text { to-face } \\
(\mathbf{n}=\mathbf{1 1 3 3})\end{array}$ & $\begin{array}{c}\text { Some } \\
\text { face-to- } \\
\text { face, some } \\
\text { self-study } \\
(\mathbf{n}=347)\end{array}$ & $\begin{array}{c}\text { Self-study } \\
\text { only } \\
(\mathbf{n}=417)\end{array}$ & $\begin{array}{c}\text { Could } \\
\text { not access } \\
\text { content } \\
\text { (n=36) }\end{array}$ \\
\hline Time management & $60 \%$ & $53 \%$ & $56 \%$ & $39 \%$ \\
\hline $\begin{array}{l}\text { Difficulty adjusting to the } \\
\text { new environment }\end{array}$ & $57 \%$ & $53 \%$ & $55 \%$ & $61 \%$ \\
\hline How to effectively study & $53 \%$ & $50 \%$ & $43 \%$ & $25 \%$ \\
\hline Financial pressure & $29 \%$ & $31 \%$ & $35 \%$ & $33 \%$ \\
\hline $\begin{array}{l}\text { Where to get academic } \\
\text { support }\end{array}$ & $26 \%$ & $26 \%$ & $28 \%$ & $44 \%$ \\
\hline $\begin{array}{l}\text { No electronic devices/ } \\
\text { internet }\end{array}$ & $16 \%$ & $23 \%$ & $34 \%$ & $64 \%$ \\
\hline Social pressure & $10 \%$ & $11 \%$ & $16 \%$ & $17 \%$ \\
\hline Accommodation & $8 \%$ & $8 \%$ & $8 \%$ & $3 \%$ \\
\hline Food security & $4 \%$ & $8 \%$ & $7 \%$ & $17 \%$ \\
\hline Working while studying & & $29 \%$ & $8 \%$ \\
\hline
\end{tabular}

Students were then asked if UFS101 assisted with their transition to university (Table 5).

Table 5: The assistance of UFS101 in transition to university

\begin{tabular}{|l|c|c|c|}
\hline Category & Yes & No & No answer \\
\hline Face-to-face & $90 \%$ & $8 \%$ & $2 \%$ \\
\hline $\begin{array}{l}\text { Some face-to-face, } \\
\text { some self-study }\end{array}$ & $90 \%$ & $10 \%$ & $1 \%$ \\
\hline Self-study only & $83 \%$ & $15 \%$ & $2 \%$ \\
\hline Could not access content & $33 \%$ & $61 \%$ & $6 \%$ \\
\hline
\end{tabular}


Students were asked to provide reasons why UFS101 assisted with their transition to university, and the majority of students agreed that it was through the content that was taught (face-to-face [67\%], some face-to-face, some self-study [67\%], and self-study only [64\%]). In this specific item, students who could not access the content ranged between $25 \%$ and $42 \%$ for all the selected items. Only $12 \%$ of the self-study only students selected the "by meeting other first-year students", as the nature of their interaction with the institution was for a brief period of time within their first year, and they did not have the opportunity to engage with the UFS101 summer school face-to-face.

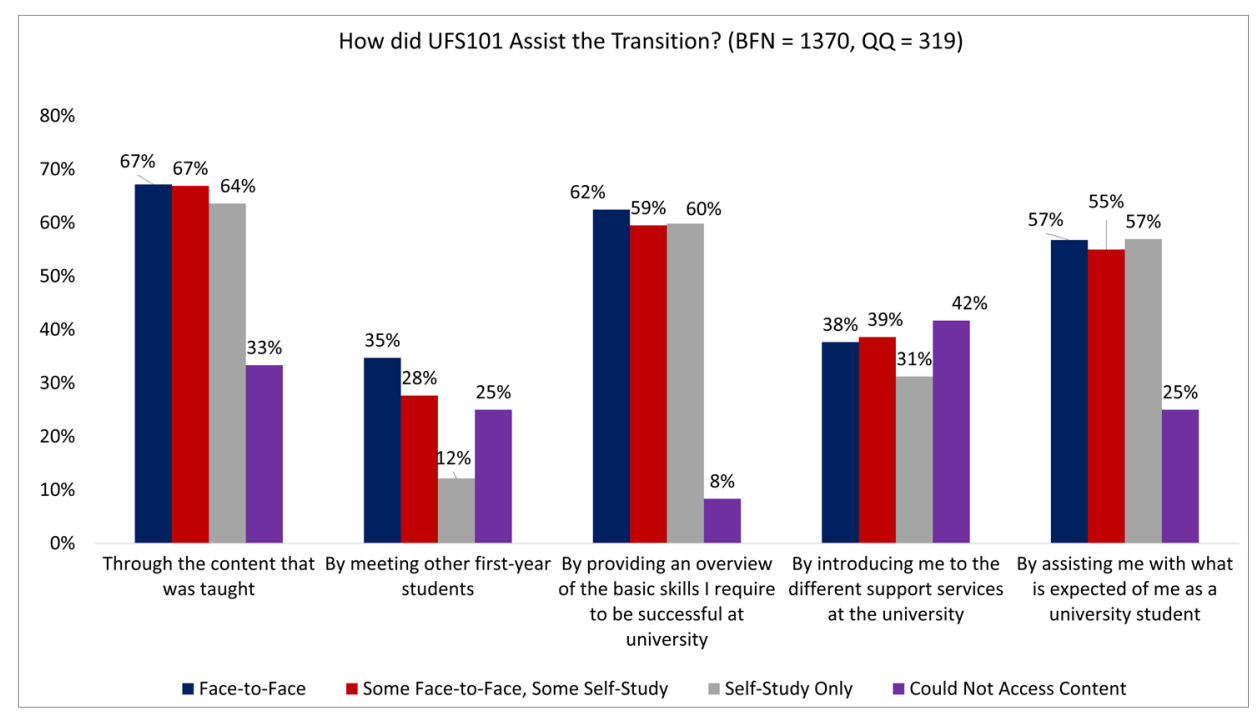

Figure 1: The ways in which UFS101 assisted student transition into university

In the context of the four groups, the self-study only students are a representative sample of students who could only engage with the content online, and they reported that the UFS101 content assisted them with what is expected of them at university (57\%). In addition to this, the self-study group reported that UFS101 provided an overview of the basic skills they require to be successful within university (60\%). This specific part of the cohort illustrated that the content was sufficient in assisting student transition, but illustrated the lack of social cohesion that the other students experienced (face-to-face (35\%), some face-to-face, some self-study (28\%)) as a result of the physical interaction with other students.

Students were asked if they had a positive or negative experience with UFS101. Overall, students reported that they had more of a positive experience with UFS101 than an undecided or negative experience. The majority of students who could not access the content did not have a positive or negative experience of UFS101. 


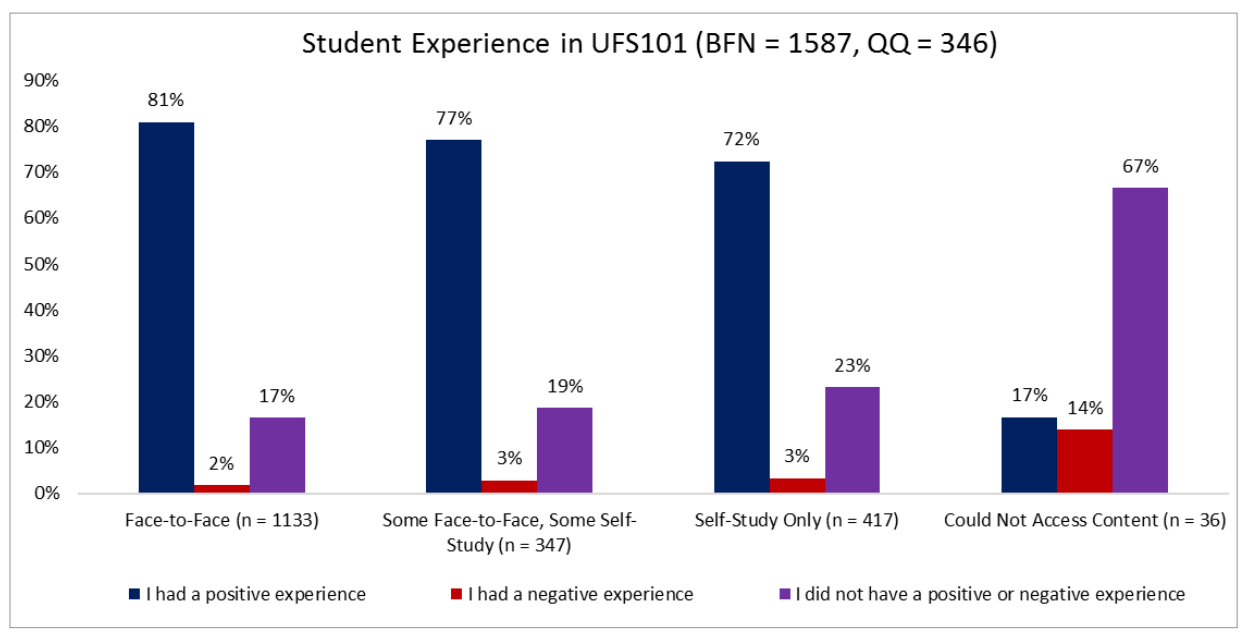

Figure 2: Student experience within of the first semester of UFS101

Students who said that they had a positive experience with the content were then further asked to provide context around why they had a positive experience. In total, 1486 students' responses were taken into consideration $(B F N=1196, Q Q=290)$. When their responses were stratified according to the four categories, a few unique themes emerged. The first theme was that across all four categories, the majority of students attributed their positive experience to learning something new. In addition to this, face-to-face (65\%), some face-to-face, some self-study (68\%), and self-study only (65\%) reported that UFS101 broadened their perspectives around concepts that they did not know. According to Dziewanowska (2017), an opportunity for development presents itself when students are learning new things, and equally, broadens their perspectives. Lastly, the biggest difference between the groups was observed in the reason why students had a positive experience, as seen in Figure 3.

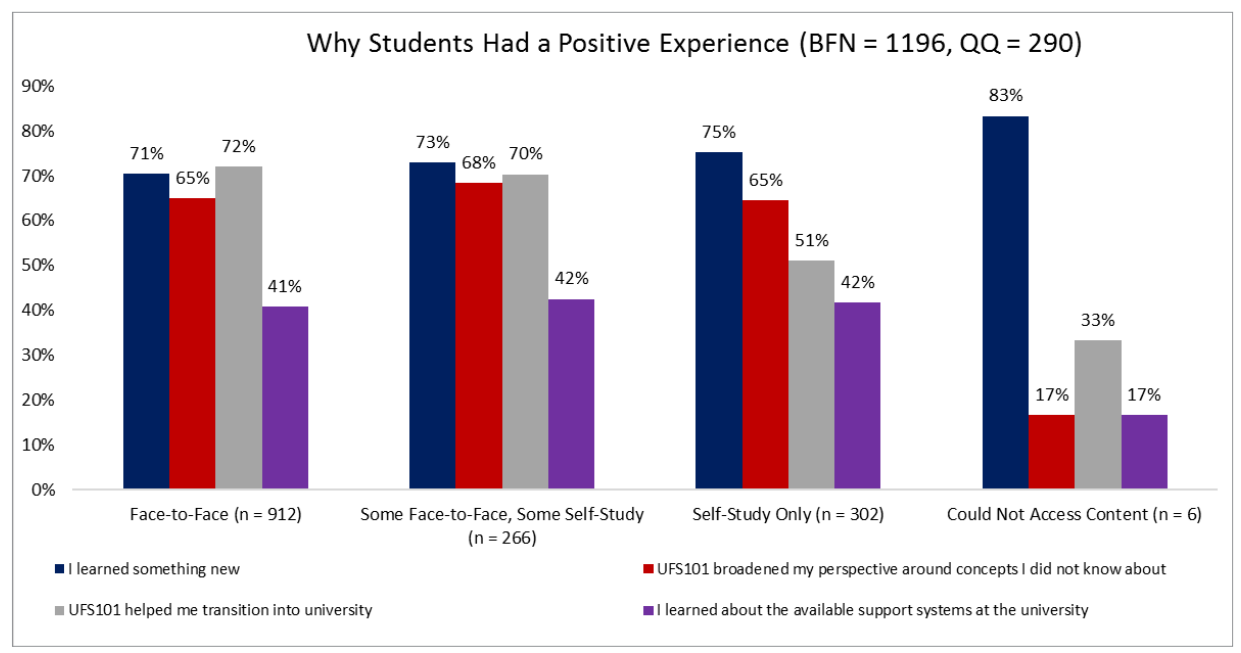

Figure 3: Reasons for positive student experience of UFS101 in the first semester 
As observed in Figure 3, there was a significantly higher percentage of students who had a face-to-face interaction, or some face-to-face interaction that attributed the positive experience with UFS101 to the module assisting with the transition into university, than students who did not have that interaction. This strengthens the argument that content alone is not enough in student transition (Upcraft et al., 2005; Kuh, 2008; Young, 2016) and suggests that the benefit of face-to-face interaction be further investigated as a contributor to a successful transition to university. An important finding was that the differences and similarities reported on was consistent across students from different faculties or fields of study.

\section{Conclusion}

According to Gadinger (2014), immense pressure is placed upon institutions to produce more graduates - this requires an intentional focus on improving student transition. According to Kuh (2008), implementing FYE programmes as HIPs contributes towards successful student transition. In this study, the impact of COVID-19 and the ensuing national lockdown on the FYS at the UFS was investigated. The descriptive observation highlighted that there were unique differences between the four stratified groups that need to be explored further, such as the challenges students face in the first six months of university and the effect of different modes of delivery (face-to-face vs online selfstudy) on student transition. COVID-19 brought with it a reminder that institutions of higher learning need to not only scale online learning for all students, but also acknowledge the challenges that accompany online learning. Some of these include investigating the technological needs of students who cannot access university information, and exploring the differences between a face-to-face model and a blend of face-to-face and online in terms of student success. Lastly, this type of investigation should be regularly performed to understand first-year transition and how to effectively implement a FYS, and thus optimally support first-year students.

\section{Acknowledgements}

We would like to thank each participant in this study. Without their valuable input and contribution, this study would not have been possible. We would also like to thank the Centre for Teaching and Learning at the University of the Free State for their resources which enabled us to conduct this study during these unprecedented times.

\section{References}

Achille, C., Fassi, F, Mandelli, A. \& Fiorillo, F. (2018). Surveying Cultural Heritage: Summer School for Conservation Activities. Applied Geomatics, 10(4), 579-592. https://doi.org/10.1007/s12518-018$0225-3$

Adams, R. \& Blair, E. (2019). Impact of Time Management Behaviors on Undergraduate Engineering Students' Performance. SAGE Open, 1(9), P.2158244018824506. https://doi.org/10.1177/215824 4018824506

Amir Singh,J. (2020). How South Africa's Ministerial Advisory Committee on Covid-19 can be Optimised. South African Medical Journal, 110(6), 1-1. https://doi.org/10.7196/SAMJ.2020v110i6.14840 
Barefoot, B. (2004). Higher Education's Revolving Door: Confronting the Problem of Student Drop Out in US Colleges and Universities. Open Learning: The Journal of Open, Distance and E-Learning, 19(1), 9-18. https://doi.org/10.1080/0268051042000177818

Bir, B. \& Myrick, M. (2015). Summer Bridge's Effects on College Student Success. Journal of Development Education, 1(39), 22-30.

Boeije, H., Slagt, M. \& Van Wesel, F. (2013). Mixed Methods Practice: Research Purposes and Designs. Journal of Mixed Methods Research, 7(4), 347-369. https://doi.org/10.1177/1558689813482756

Burd, E. \& Hodgson, B. (2006). Attendance and Attainment: A Five Year Study. Innovation in Teaching and Learning in Information and Computer Sciences, 5(2),1-12.https://doi.org/10.11120/ital.2006.05020004

Buyarski, C. \& Landis, C. (2014). Using an Eportfolio to Assess the Outcomes of a First-Year Seminar: Student Narrative and Authentic Assessment. International Journal of Eportfolio, 4(1), 49-60.

Chastonay, P. \& Mpinga, E. (2018). The Geneva University Global Health and Human Rights Summer School: A 5-Year Intercultural Collaborative Experience. Frontiers In Public Health, 6, 128. https://doi. org/10.3389/fpubh.2018.00128

Chism, L.A.W.G. (2008). Implementation of First-Year Seminars, the Summer Academy Bridge Program, and Themed Learning Communities. Metropolitan Universities, 2(19), 8-17.

Colombo, C. \& Falcone, Y. (2016). First International Summer School on Runtime Verification. Cham, Switzerland: Springer. https://doi.org/10.1007/978-3-319-46982-9_2

Cooper, K., Ashley, M. \& Brownell, S. (2017). A Bridge to Active Learning: A Summer Bridge Program Helps Students Maximize Their Active-Learning Experiences and the Active-Learning Experiences of Others. CBE - Life Sciences Education, 1(16), 17. https://doi.org/10.1187/cbe.16-05-0161

Crissman, J. (2001). Clustered and Nonclustered First-Year Seminars: New Students' First-Semester Experiences. Journal of the First-Year Experience \& Students in Transition, 13(1), 69-88.

Culver, K. \& Bowman, N. (2019). Is what Glitters Really Gold? A Quasi-Experimental Study of First-Year Seminars and College Student Success. Research In Higher Education, 1-30. https://doi.org/10.1007/ s11162-019-09558-8

DHET (Department of Higher Education and Training) (2017). Research Agenda 2014-2017. https:// www.dhet.gov.za/ [Accessed 2 September 2020].

Dziewanowska, K. (2017). Value Types in Higher Education-Students' Perspective. Journal of Higher Education Policy and Management, 39(3), 235-246. https://doi.org/10.1080/1360080X.2017.1299981

Eblen-Zayas, M. \& Russell, J. (2019). Making an Online Summer Bridge Program High Touch. Journal of College Student Development, 60(1), 104-109. https://doi.org/10.1353/csd.2019.0006

Evans, S. \& Morrison, B. (2011). Meeting the Challenges of English-Medium Higher Education: The First-Year Experience in Hong Kong. English For Specific Purposes, 30(3), 198-208. https://doi. org/10.1016/j.esp.2011.01.001

Fallows, S. \& Steven, C. (2000). Building Employability Skills into the Higher Education Curriculum: A University-Wide Initiative. Education Training, 42(2), 75-83. https://doi.org/10.1108/004009100 10331620

Gadinger, B. (2014). The Influence of Compulsory Class Attendance on Module Success Rates: The University of the Free State Case. Doctoral dissertation, University of the Free State, Bloemfontein.

Gellin, A. (2003). The Effect of Undergraduate Student Involvement on Critical Thinking: A MetaAnalysis of the Literature. Journal of College Student Development, 44(6), 746-762. https://doi.org/ $10.1353 /$ csd.2003.0066

Hansen, M. \& Schmidt, L. (2017). The Synergy of and Readiness for High-Impact Practices during the First Year of College. Journal of the First-Year Experience \& Students in Transition, 1(29), 57-82. 
Hatefi, S., Smith, F., Abou-El-Hossein, K. \& Alizargar, J. (2020). Covid-19 in South Africa: Lockdown Strategy and its Effects on Public Health and Other Contagious Diseases. Public Health, 185, 159. https://doi.org/10.1016/j.puhe.2020.06.033

Henderson, K. (2011). Post-Positivism and the Pragmatics of Leisure Research. Leisure Sciences, 4(33), 341-346. https://doi.org/10.1080/01490400.2011.583166

Henn, M., Hen-Boisen, L. \& Posthumus, H. (2017). Understanding and Supporting Students Entering Higher Education. In: F. Strydom, G. Kuh \& S. Loots (Eds.), Engaging Students: Using Evidence to Promote Student Success (pp. 55-59). Bloemfontein: Sun Media.

Kretovics, M., Crowe, A. \& Hyun, E. (2005). A Study of Faculty Perceptions of Summer Compressed Course Teaching. Innovative Higher Education, 1(30), 37-51. https://doi.org/10.1007/s10755-005$3295-1$

Kuh, G. (2008). Excerpt from High-Impact Educational Practices: What They Are, Who Has Access to Them, and Why They Matter. Association of American Colleges And Universities, 14(3), 28-29.

Larsen, P.G., Kristiansen, E., Bennedsen, J. \& Bjerge, K. (2017). Enhancing Non-Technical Skills by a Multidisciplinary Engineering Summer School. European Journal of Engineering Education, 42(6), 1076-1096. https://doi.org/10.1080/03043797.2016.1261278

Mah, D. \& Ifenthaler, D. (2017). Academic Staff Perspectives on First-Year Students' Academic Competencies. Journal of Applied Research in Higher Education, 9(4), 1-3. https://doi.org/10.1108/ JARHE-03-2017-0023

Marivate,V. \& Combrink, H. (2020). Use of Available Data to Inform the Covid-19 Outbreak in South Africa: A Case Study. Data Science Journal, 1(9), 1-5. https://doi.org/10.5334/dsj-2020-019

Morse, J. (2010). Procedures and Practice of Mixed Method Design: Maintaining Control, Rigor, and Complexity. Second edition. Thousand Oaks, CA: SAGE Handbook of Mixed Methods in Social \& Behavioral Research.

Myers, C., Myers, S. \& Peters, M. (2019). The Longitudinal Connections Between Undergraduate High Impact Curriculum Practices and Civic Engagement in Adulthood. Research in Higher Education, 1(60), 83-110. https://doi.org/10.1007/s11162-018-9504-4

Newman-Ford, L., Fitzgibbon, L., Lloy, S. \& Thomas, S. (2008). A Large-Scale Investigation into the Relationship Between Attendance and Attainment: A Study Using an Innovative, Electronic Attendance Monitoring System. Studies in Higher Education, 33(6), 699-717. https://doi.org/10.10 80/03075070802457066

Osseni, I. (2020). Covid-19 Pandemic in Sub-Saharan Africa: Preparedness, Response, and Hidden Potentials. Tropical Medicine and Health, 48(1), 1-3. https://doi.org/10.1186/s41182-020-00240-9

Parker, J., Summerfeldt, L., Hogan, M. \& Majeski, S. (2004). Emotional Intelligence and Academic Success: Examining the Transition from High School to University. Personality and Individual Differences, 36(1), 163-172. https://doi.org/10.1016/S0191-8869(03)00076-X

Porter, S. \& Swing, R. (2006). Understanding How First-Year Seminars Affect Persistence. Research in Higher Education, 47(1), 89-109. https://doi.org/10.1007/s11162-005-8153-6

Ricciardi, F. (2009). Epistemology of Information Systems: Time for Something New? Positivism, Interpretivism, and Beyond. Information Systems: People, Organizations, Institutions, and Technologies, pp. 267-275. https://doi.org/10.1007/978-3-7908-2148-2_31

Sreejesh, S. \& Mohapatra, S. (2014). Mixed Method Research Design. In: Discussion, Implications, and Conclusions (pp. 109-116). Cham, Switzerland: Springer. https://doi.org/10.1007/978-3-31902687-9_6

Starke, M., Harth, M. \& Sirianni, F. (2001). Retention, Bonding, and Academic Achievement: Success of a First-Year Seminar. Journal of the First-Year Experience \& Students in Transition, 13(2), 7-36. 
Stoller, A. (2019). Critical Inquiry and the First Year: Reconceptualizing the Aims of Transitions Pedagogies. Journal of General Education, 3-4(66), 99-113. https://doi.org/10.5325/jgeneeduc.66. 3-4.0099

Strayhorn, T. (2009). An Examination of the Impact of First-Year Seminars on Correlates of College Student Retention. Journal of the First-Year Experience \& Students in Transition, 1(21), 9-27.

Strydom, F., Kuh, G. \& Loots, S. (2017). Engaging Students: Using Evidence to Promote Student Success. First edition. Bloemfontein: Sun Media. https://doi.org/10.18820/9781928424093

Strydom, F. \& Loots, S. (2018). Where is the Rest of the Class? A Study of Class Attendance at the University of the Free State. Bloemfontein: EBC, Centre for Teaching and Learning.

Thomsen, J. (2012). Exploring the Heterogeneity of Class in Higher Education: Social and Cultural Differentiation. British Journal of Sociology of Education, 4(33), 565-585. https://doi.org/10.1080/014 25692.2012.659458

Tinto,V. (1987). Leaving College: Rethinking the Causes and Cures of Student Attrition. Chicago, Ill: University of Chicago Press.

Tinto,V. \& Goodshell, A. (1994). Freshman Interest Groups and the First-Year Experience: Constructing Student Communities in a Large University. Journal of the First-Year Experience $\mathcal{E}$ Students in Transition, 6(1), 7-28.

Tomasko, D., Ridgway, J., Waller, R. \& Olesik, S. (2016). Association of Summer Bridge Program Outcomes with STEM Retention of Targeted Demographic Groups. Journal of College Science Teaching, 4(45), 90. https://doi.org/10.2505/4/jcst16_045_04_90

Townsend, L. (1994). How Universities Successfully Retain and Graduate Black Students. The Journal of Blacks in Higher Education, 4(1), 85-89. https://doi.org/10.2307/2963380

Ulriksen, L., Madsen, L. \& Holmegaard, H. (2017). The First-Year Experience of Non-Traditional Students in Danish Science and Engineering University Programmes. European Educational Research Journal, 1(16), 45-61. https://doi.org/10.1177/1474904116678628

Upcraft, M. \& Gardner,J. (1989). The Freshman Year Experience. Helping Students Survive and Succeed in College. San Francisco, CA: Jossey-Bass.

Upcraft, M., Gardner, J. \& Barefoot, B. (2005). Challenging and Supporting the First-Year Student: A Handbook for Improving the First Year of College. 254 Edition. San Francisco, CA: Jossey-Bass.

Van Breda, A. (2017). Students are Humans Too: Psychosocial Vulnerability of First-Year Students at the University of Johannesburg. South African Journal of Higher Education, 5(31), 246-262. https://doi. org/10.20853/31-5-1567

Velazquez-Torres, N. (2018). Setting Students Up for Life Long Success Through Innovative Summer Bridge Programs and First Year Seminars. HETS Online Journal, 2(8), 88-104.

Vinas-Forcade, J., Mels, C., Valcke, M. \& Derluyn, I. (2019). Beyond Academics: Dropout Prevention Summer School Programs in the Transition to Secondary Education. International Journal Of Educational Development, 70, P.102087. https://doi.org/10.1016/j.jjedudev.2019.102087

Yan, Z. \& Sendall, P. (2016). First-Year Experience: How We Can Better Assist First-Year International Students in Higher Education. Journal of International Students, 1(6), 35-51.

Young, D. (2016). The Case for an Integrated Approach to Transition Programmes at South Africa's Higher Education Institutions. Journal of Student Affairs in Africa, 1(4), 17-32. https://doi.org/10.14426/jsaa. v4i1.142

\section{How to cite:}

Combrink, H.M.v.E. \& Oosthuizen, L.L. 2020. First-Year Student Transition at the University of the Free State during COVID-19: Challenges and Insights. Journal of Student Affairs in Africa, 8(2), 31-44. DOI: $10.24085 /$ jsaa.v8i2.4446 